\title{
近赤外レーザを用いた銅の微細溶接における開口数と表面粗さの影響
}

\section{Influence of Numerical Aperture and Surface Roughness on Micro-welding Characteristics of Copper Using Near Infrared Laser}

\author{
○学 川崎 将大"1, 濱田 一樹"1, 岡本 康寛*1 \\ 岡田 晃 ${ }^{* 1}$, 西 則男 ${ }^{* 2}$, 酒川 友一 ${ }^{* 2}$
}

Shota KAWASAKI ${ }^{* 1}$, Kazuki HAMADA ${ }^{* 1}$,Yasuhiro OKAMOTO*1,

Akira OKADA $^{* 1}$, Norio NISHI ${ }^{* 2}$ and Tomokazu SAKAGAWA ${ }^{* 2}$

${ }^{* 1}$ 岡山大学 Okayama University

*2 株式会社片岡製作所 Kataoka Corporation

Key Words : Nd:YAG レーザ，微細溶接，銅，表面粗さ，開口数

近年，様々な電子機器が小型化，軽量化されるにともなって銅の微細加工および微細接合に関する要求が増大 している(1). しかし，波長 $1064 \mathrm{~nm}$ と近赤外に属する Nd:YAG レーザを用いた場合，銅は非常に高い光反射率を 示寸ため, 不安定な溶接現象となることが多く, その改善が望まれている. そこで, 波長 $1064 \mathrm{~nm} の \mathrm{Nd:YAGレ}$ 一ザを用いた場合における開口数と表面粗さの影響について実験的に検討を行った.

図 1 に本実験で使用した波長 $1064 \mathrm{~nm}$ のパルス Nd:YAG レーザを用いた実験方法を模式的に示す. 図の上から 開口数 $0.11 ， 0.16,0.21$ の場合を示しており, 開口数の值を 0.05 ずつ変化させつつ, 開口数 $0.16,0.21$ では光源 側へディフォーカスさせることにより全ての開口数で同等のスポット直径 $35 \mu \mathrm{m}$ を得た． パルス幅 $1.2 \mathrm{~ms}$ の矩形 波を用い, ピーク出力を制御して全ての開口数において熱伝導型とキーホール型溶接の遷移条件となるようにし, 窒素をシールドガスとして $50 \mathrm{~L} / \mathrm{min}$ で供給した．加工試料には厚さ $1.0 \mathrm{~mm}$ の無酸素銅 C1020(JIS)を使用した.

図 2 に熱伝導型とキーホール型の 2 つの溶接形態が混在する遷移条件において, 開口数と試料表面粗さを変化 させた場合における溶融形態を示す. 溶接形態の評価基準は, レーザ光照射を 10 回行った場合, 全てキーホール

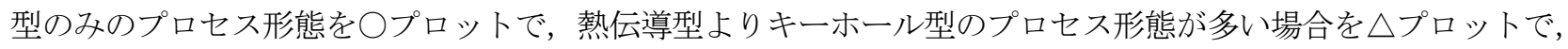
キーホール型より熱伝導型のプロセス形態が多い場合をメプロットで表している. 図より, 開口数の值が大きく なると, 安定したキーホールの生成が得られる最大高さ粗さ Rz の值が小さくなっており, プロセス形態が安定 する表面粗さと開口数には相関性があることが明らかとなった.

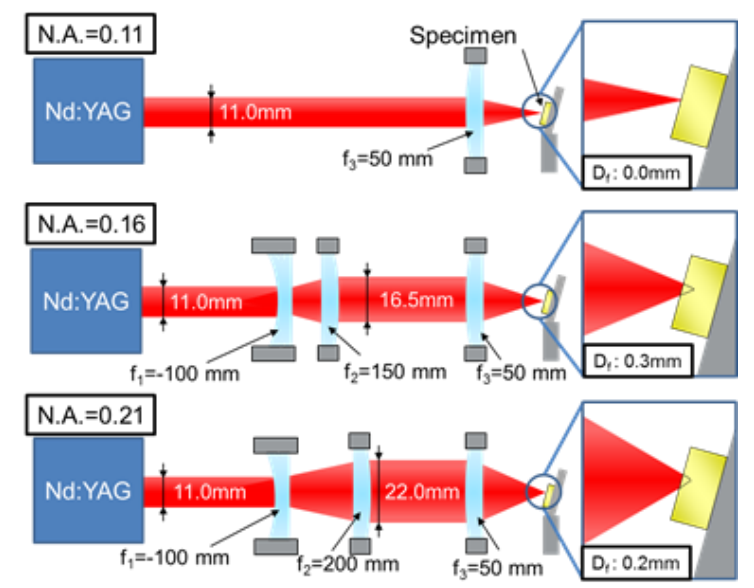

Fig. 1 Schematic diagram of laser irradiation setup for various numerical apertures

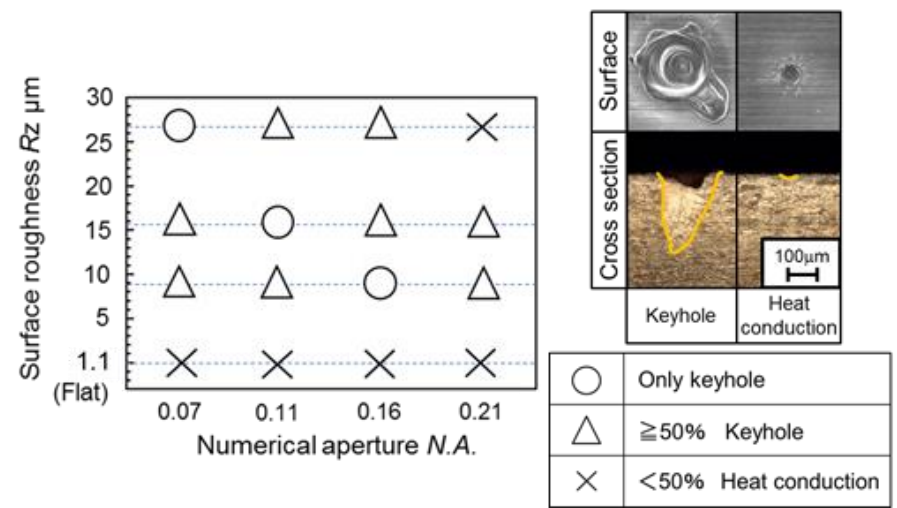

Wavelength: $\lambda=1064 \mathrm{~nm}$, Pulse duration: $\mathrm{t}_{\mathrm{p}}=1.2 \mathrm{~ms}$, Shielding gas: $\mathrm{N}_{2}=50 \mathrm{~L} / \mathrm{min}$, Specimen: $\mathrm{C} 1020(\mathrm{t}=1.0 \mathrm{~mm})$

Fig. 2 Welding types for different surface roughness using various numerical apertures

文献

（1）金属材料活用事典編集委員会：金属材料活用事典，産業調査会，(2000), pp.74-77, pp.648-650. 